\title{
PENGARUH TEMPERATUR PADA PROSES PEMURNIAN MINYAK GORENG BEKAS DENGAN BUAH MENGKUDU
}

\author{
Frima Viantini $A^{1}$, Yustinah ${ }^{2}$ \\ ${ }^{2}$ Jurusan Teknik Kimia, Fakultas Teknik \\ Universitas Muhammadiyah Jakarta \\ yus_tin@yahoo.com
}

\begin{abstract}
ABSTRAK Mengkudu (Morinda citrifolia L) merupakan bahan adsorben karena antioksidan yang terkandung di dalamnya. Antioksidan tersebut berguna untuk mengikat pengotor dan membentuk senyawa kompleks yang dapat dimanfaatkan untuk peningkatan kualitas minyak goreng bekas. Penelitian ini bertujuan untuk mempelajari pengaruh temperatur pada penambahan buah mengkudu yang dimanfaatkan sebagai adsorben terhadap penurunan kadar asam lemak bebas, angka peroksida, dan kepekatan warna pada minyak goreng bekas. Percobaan dilakukan dengan menggunakan metode adsorbsi dengan tahapan proses sebagai berikut proses despicing, proses netralisasi, proses bleaching dengan variasi temperatur $50^{\circ} \mathrm{C}$, $60^{\circ} \mathrm{C}, 70^{\circ} \mathrm{C}, 80^{\circ} \mathrm{C}, 90^{\circ} \mathrm{C}$ selama 60 menit dengan konsentrasi buah mengkudu $20 \%$ dan kecepatan pengadukan $500 \mathrm{rpm}$. Analisa hasil uji pemurnian minyak goreng pada percobaan ini meliputi beberapa parameter yaitu bilangan asam, kadar asam lemak bebas, bilangan peroksida, serta bilangan warna. Dari hasil percobaan didapat temperatur optimal adalah pada temperatur $70^{\circ} \mathrm{C}$ dengan konsentrasi $20 \%$ buah mengkudu dan kecepatan pengadukan $500 \mathrm{rpm}$ selama 60 menit dan didapatkan bilangan asam $0.3293 \mathrm{mgrek} / \mathrm{mg}$, kadar asam lemak bebas 0,2108\%, bilangan peroksida $1.65 \mathrm{meq} / \mathrm{kg}$, dan absorbansi pada panjang gelombang $450 \mathrm{~nm}$ adalah 0.82 .
\end{abstract}

Kata Kunci : Adsorbsi, mengkudu, minyak goreng bekas, pemurnian

\section{PENDAHULUAN}

\section{Latar Belakang}

Sebagian besar masyarakat Indonesia, menggunakan minyak goreng dengan berkali-kali pemakaian sebagai media untuk menggoreng (minyak jelantah) dengan tujuan penghematan. Padahal minyak goreng akan menurun kualitasnya seiring dengan pemanasan yang berulang-ulang.

Berbagai macam kerusakan akibat proses oksidasi, hidrolisis, polimerisasi dan reaksi dengan logam menyebabkan minyak menjadi berwarna kecoklatan, lebih kental, berbusa, berasap serta meninggalkan odor yang tidak disukai pada makanan hasil gorengan (Ketaren, 1986).

Salah satu upaya yang dapat dilakukan adalah dengan proses pemurnian kembali minyak goreng bekas dengan menggunakan bantuan adsorben yaitu buah mengkudu yang bertujuan dapat mendekati karakteristik minyak goreng segar, memperpanjang umur minyak goreng, dan keamanan pemakaian.

Buah mengkudu merupakan salah satu bahan yang digunakan sebagai pemurnian minyak goreng dikarenakan fungsinya sebagai adsorben dan pengkelat dimana senyawa mempunyai kemampuan mencegah kerusakan dan menstabilkan radikal bebas.

Penjernihan minyak jelantah dipengaruhi oleh beberapa faktor yang mendasarinya yaitu : Jumlah massa adsorben yang digunakan sebagai media penyerap; Jenis adsorben yang digunakan, adsorben yang baik adalah yang memiliki fungsi yang baik dan aman digunakan; Kecepatan pengadukan pada proses adsorbsi (rpm); Temperatur pemanasan saat proses adsorbsi; Waktu pengadukan saat proses adsorbsi.

Penelitian ini dimaksudkan untuk mengetahui sejauh mana pengaruh 
temperatur pada proses pemurnian minyak goreng bekas menggunakan buah mengkudu dalam menurunkan angka peroksida, kadar asam lemak bebas dan kepekatan warna pada minyak goreng bekas.

\section{Minyak Goreng Bekas (Jelantah)}

Jelantah adalah minyak goreng yang telah berulang kali digunakan. Jelantah berwarna coklat kehitaman, bau tengik, kaya akan asam lemak bebas, sehingga menyebabkan potensi kanker meningkat.

Tanda awal dari kerusakan minyak goreng adalah terbentuknya akrolein, terbentuk dari hidrasi gliserol yang membentuk aldehida tidak jenuh. Kerusakan minyak lainnya adalah reaksi oksidasi pada minyak yang mula-mula akan membentuk peroksida dan hidroperoksida, kemudian selanjutnya akan terkonversi menjadi aldehida, keton dan asam-asam lemak bebas. Rancidity (ketengikan) terbentuk oleh adanya aldehida, bukan terbentuk oleh adanya peroksida. Jadi kenaikan angka peroksida (PV) merupakan indikator bahwa minyak sebentar lagi akan berbau tengik (Ketaren 1986).

\section{Kerusakan Minyak}

Kerusakan minyak, umumnya terjadi karena : (1) Penyerapan bau. Lemak bersifat mudah menyerap bau dan lemak yang terserap dapat teroksidasi oleh udara sehingga rusak dan berbau; (2). Hidrolisis. Adanya air mengakibatkan lemak terhidrolisis menjadi gliserol dan asam lemak. Reaksi ini dipercepat oleh basa, asam, dan enzim-enzim. Hidrolisis menurunkan mutu minyak goreng, akibatnya asam lemak bebas bertambah dan harus dihilangkan dengan proses pemurnian dan deodorisasi;(3) Oksidasi dan ketengikan, disebabkan oleh proses otooksidasi radikal asam lemak tidak jenuh dalam minyak. Otooksidasi dimulai dengan pembentukan faktorfaktor yang dapat mempercepat reaksi seperti cahaya, panas, peroksida lemak atau hidroperoksida, logam-logam berat, dan enzim-enzim lipoksidase; (5) Polimerisasi; pembentukan suatu senyawa polimer selama proses menggoreng terjadi karena reaksi polimerisasi adisi dari asam lemak tidak jenuh, mudah terjadi pada minyak yang mengandung asam-asam lemak tidak jenuh dalam jumlah besar. (Ketaren, 1986)

Warna akibat oksidasi dan degradasi komponen kimia yang terdapat dalam Minyak : (1) Warna gelap, disebabkan oleh proses oksidasi terhadap tokoferol (Vitamin E). jika minyak bersumber dari tanaman hijau, maka zat klorofil turut terekstrak bersama minyak, dan sulit dipisahkan dari minyak; (2) Warna Coklat, pigmen coklat terdapat pada minyak berasal dari bahan yang telah busuk, karena reaksi molekul karbohidrat dengan gugus pereduksi seperti aldehid serta gugus amin dari molekul protein dan disebabkan oleh karena aktivitas enzim-enzim seperti phenol oxidase, polyphenol oxidase, dan sebagainya. (3) Warna Kuning, timbul selama penyimpanan dan intensitas warna bervariasi dari kuning sampai ungu kemerah-merahan. (Ketaren,1986)

\section{Buah Mengkudu}

Mengkudu berasal daerah Asia Tenggara, tergolong dalam famili Rubiaceae. Tanaman ini tumbuh di dataran rendah hingga pada ketinggian $1500 \mathrm{~m}$. Tinggi pohon mengkudu mencapai 3-8 $\mathrm{m}$, memiliki bunga bongkol berwarna putih. Buahnya merupakan buah majemuk. Kandungan dalam mengkudu : (1) Nutrisi yang dibutuhkan tubuh, seperti protein, viamin, dan mineral, tersedia dalam jumlah cukup pada buah dan daun mengkudu. Selenium, salah satu mineral yang terdapat pada mengkudu merupakan antioksidan. (2) Anti bakteri, merupakan zat aktif yang terkandung dalam sari buah mengkudu itu dapat mematikan bakteri penyebab infeksi, seperti Pseudomonas aeruginosa, Protens morganii, Staphylococcus aureus, Bacillus subtilis, dan 
Escherichia coli, (3) Anti kanker. Zat-zat anti kanker yang terdapat pada mengkudu paling efektif melawan selsel abnormal.

\section{Adsorpsi}

Sorpsi adalah proses penyerapan ion oleh partikel penyerap. Sorpsi dibedakan menjadi dua yaitu adsorpsi dan absorpsi. Dinamakan proses adsorpsi jika ion atau senyawa yang diserap tertahan pada permukaan partikel penyerap. Jika proses pengikatan berlangsung sampai di dalam partikel penyerap disebut absorpsi (Handayani dan Sulistiyono. 2009).

Bernasconi dkk, 1995 menerangkan bahwa adsorpsi adalah suatu proses pemisahan bahan dari campuran gas atau cair, bahan yang harus dipisahkan ditarik oleh permukaan sorben padat dan diikat oleh gaya-gaya yang bekerja pada permukaan tersebut. Kecepatan adsorpsi tergantung pada perbedaan konsentrasi, luas permukaan adsorben, suhu, tekanan (untuk gas), ukuran partikel, dan porositas adsorben. Kecepatan adsorpsi juga tergantung pada ukuran molekul bahan yang akan disorpsi dan pada viskositas campuran yang akan dipisahkan (cairan, gas) (Bernasconi, dkk, 1995).

Menurut Oscik (1991), adsorpsi dapat dikelompokkan menjadi dua, yaitu: (1) Adsorpsi Fisik (Fisisorpsi), merupakan suatu proses bolak-balik apabila daya tarik menarik antara zat terlarut dan adsorben lebih besar daya tarik menarik antara zat terlarut dengan pelarutnya maka zat yang terlarut akan diadsorpsi pada permukaan adsorben. Molekul yang terbentuk dari adsorpsi fisika terikat sangat lemah dan energi yang dilepaskan pada adsorpsi fisika relatif rendah sekitar $20 \mathrm{kj} / \mathrm{mol}$, karena itu sifat adsorpsinya adalah reversible (Oscik, 1991); (2) Adsorpsi Kimia (Kemisorpsi), merupakan interaksi adsorbat dengan adsorben melalui pembentukan ikatan kimia. Kemisorpsi terjadi diawali dengan adsorpsi fisik, yaitu partikel-partikel adsorbat mendekat ke permukaan adsorben melalui gaya Van der Waals atau melalui ikatan hidrogen, kemudian diikuti oleh adsorpsi kimia partikel melekat pada permukaan dengan membentuk ikatan kimia (biasanya ikatan kovalen), dan cenderung mencari tempat yang memaksimumkan bilangan koordinasi dengan substrat. Molekul yang terbentuk dari adsorpsi kimia lebih kuat dibandingkan dengan yang terbentuk dari adsorpsi fisika, karena energi yang dilepaskan cukup besar sekitar $400 \mathrm{~kJ} / \mathrm{mol}$.

\section{Pemurnian Minyak}

1. Penghilangan Bumbu (Despicing), merupakan proses pengendapan dan pemisahan kotoran akibat bumbu dan kotoran dari bahan pangan yang bertujuan menghilangkan partikel halus tersuspensi atau terbentuk koloid seperti protein, karbohidrat, garam, gula, serta bumbu rempah-rempah yang digunakan menggoreng bahan pangan tanpa mengurangi jumlah asam lemak bebas dalam minyak (Winarno,1997); 2.Netralisasi ialah suatu proses untuk memisahkan asam lemak bebas dari minyak atau lemak, dengan cara mereaksikan asam lemak bebas dengan basa atau pereaksi lainnya sehingga membentuk sabun \{soap stock). Kaustik soda $(\mathrm{NaOH})$ membantu dalam mengurangi zat warna dan kotoran yang berupa getah dan lendir dalam minyak. Reaksi antara asam lemak bebas dengan $\mathrm{NaOH}$ adalah sebagai berikut (Ketaren, 1986).

\section{$\mathrm{R}-\mathrm{COOH}+\mathrm{NaOH} \rightarrow \mathrm{R}-\mathrm{COONa}+\mathrm{H}_{2} \mathrm{O}$}

Asam lemak Basa Sabun Air

Sabun yang terbentuk dapat membantu pemisahan zat warna dan kotoran seperti fosfatida dan protein, dengan cara membentuk emulsi. Sabun atau emulsi yang terbentuk dapat dipisahkan dari minyak dengan cara sentrifusi; 3 Pemucatan (bleaching), ialah suatu tahap proses pemurnian untuk menghilangkan zat-zat warna yang tidak disukai dalam minyak. Pemucatan ini dilakukan dengan mencampur 
minyak dengan sejumlah kecil adsorben, seperti tanah serap (fuller earth), lempung aktif (activated clay) dan arang aktif atau dapat juga menggunakan bahan kimia. Zat warna dalam minyak akan diserap oleh permukaan adsorben dan juga menyerap suspensi koloid (gum dan resin) serta hasil degradasi minyak, misalnya peroksida (Ketaren, 1986).

\section{METODOLOGI PENELITIAN \\ Alat Penelitian}

Alat - alat yang digunakan :

Beaker Glass, erlenmeyer, hot plate dengan magnetic stirer, termometer, vacum pump, neraca sartorius, , labu kocok, statif, klem buret, saringan vakum, pipet volume, kertas saring Whatman 42.

\section{Bahan}

Bahan - bahan yang digunakan adalah : Minyak goreng bekas yang diambil dari tukang gorengan di daerah Bekasi Barat, minyak goreng baru dengan merk "SUNCO", buah mengkudu, aquadest, $\mathrm{NaOH} 15 \%, \mathrm{KOH} 0,1 \mathrm{~N}, \mathrm{KI}$ Jenuh, $\mathrm{Na}_{2} \mathrm{~S}_{2} \mathrm{O}_{3} 0,1 \mathrm{~N}$, larutan kanji, larutan Asam Asetat : Kloroform (3:2 $(v / v))$, etanol p.a.

\section{Metode Penelitian}

Dalam penelitian ini parameter yang digunakan adalah variasi temperatur pada penambahan buah mengkudu yang digunakan sebagai adsorben. Proses pemurnian ini dilakukan dengan 3 tahap yaitu tahap despicing, tahap netralisasi, dan adsorbsi. Di dalam tahap adsorbsi ini dilakukan variasi temperatur $50,60,70,80,90^{\circ} \mathrm{C}$. pada kecepatan pengadukan $500 \mathrm{rpm}$, dan waktu pengadukan selama 60 menit.

\section{Penghilangan bumbu (despicing)}

a. Minyak goreng bekas dan air ditimbang 1: 1 ke dalam beaker glass

b. Dipanaskan pada suhu $110^{\circ} \mathrm{C}$ selama 4 jam

c. Campuran air dan minyak dimasukkan ke dalam labu kocok dan diamkan selama 1 jam sehingga terjadi 2 lapisan.

d. Lapisan atas (minyak) di tampung untuk ke tahap berikutnya

\section{Proses Netralisasi}

a. Dibuat Larutan $\mathrm{NaOH}$ 15\% (15 gram $\mathrm{NaOH}$ dilarutkan di dalam $100 \mathrm{ml}$ air)

b. Minyak goreng hasil penghilangan bumbu (despicing) dipanaskan pada suhu $\pm 40^{\circ} \mathrm{C}$,

c. Ditambahkan larutan $\mathrm{NaOH}$ $15 \%$, dengan komposisi minyak $: \mathrm{NaOH}=100$ gram minyak $: 5$ $\mathrm{ml} \mathrm{NaOH} 15 \%$

d. Campuran diaduk selama 10 menit dengan 500 rpm

e. Kemudian disaring secara vakum dengan kertas saring whatman 42.

\section{Proses Pemurnian}

a. Persiapan awal buah mengkudu

- Dipilih buah mengkudu yang hampir matang

- Dicuci buah mengkudu sampai bersih dengan air

- Kemudian buah mengkudu dipotongpotong menjadi ukuran yang lebih kecil

- Buah mengkudu yang sudah berukuran kecil dihaluskan menggunakan blender

- Buah mengkudu yang telah halus siap digunakan.

b. Dipanaskan minyak goreng hasil netralisasi pada setiap variasi suhu yaitu 50, 60, 70, 80, $90^{\circ} \mathrm{C}$, selama waktu 60 menit,kemudian ditambahkan buah mengkudu dengan konsentrasi 20\% (dalam 100 gram minyak goring bekas diperlukan 20 gram buah mengkudu) ke dalam minyak goreng dan diaduk dengan kecepatan 500 rpm. 
c. Kemudian disaring secara vakum dengan kertas saring Whatman 42.

d. Minyak goreng pemurnian dianalisa dengan parameter yang telah ditentukan

\section{Metode Analisis}

Metode Analisa Pengujian Kualitas Minyak Goreng

\section{Analisa Kadar Asam Lemak Bebas}

Pada analisa ini menyatakan jumlah miligram $\mathrm{NaOH}$ yang diperlukan untuk menetralkan asam lemak bebas yang terdapat dalam satu gram minyak. Analisa FFA pada minyak menggunakan metode titrasi asam basa dengan cara :

1. Ditimbang \pm 10 gram sampel minyak ke dalam erlenmeyer $250 \mathrm{ml}$

2. Ditambahkan $100 \mathrm{ml}$ alkohol 96\% yang telah dinetralkan dengan $\mathrm{NaOH} 0,1 \mathrm{~N}$ dan indikator phenolphtalein (PP)

3. Dititrasi dengan $\mathrm{NaOH} 0,1 \mathrm{~N}$ menggunakan indikator PP sebagai penunjuk titik akhir titrasi

4. Kemudian diamati perubahan warna sampai merah jambu yang stabil selama 30 detik

Sesuai dengan besarnya bilangan asam, maka sedapat mungkin dilakukan penimbangan dan penggunaan kadar Natrium Hidroksida sesuai dengan tabel di bawah ini:

Tabel 1. Penimbangan Sampel Bilangan Asam

\begin{tabular}{|l|l|l|}
\hline $\begin{array}{l}\text { Bilangan } \\
\text { Asam }\end{array}$ & $\begin{array}{l}\text { Penimbangan } \\
\text { (gram) }\end{array}$ & $\begin{array}{l}\text { Normalitas } \\
\text { larutan } \\
\mathrm{NaOH}\end{array}$ \\
\hline $0,2-1$ & $10-20$ & 0,1 \\
\hline $1-10$ & $3-10$ & 0,1 \\
\hline $80-180$ & $2-6$ & 0,5 \\
\hline $\begin{array}{l}160- \\
260\end{array}$ & $1-4$ & 0,5 \\
\hline
\end{tabular}

2. Analisa Bilangan Peroksida

Peroxide Value adalah indikasi dari jumlah oksigen aktif dalam sampel yang mengoksidasi Kalium Iodida dengan kondisi metode ini. Peroxide value dinyatakan sebagai meq $\mathrm{O}_{2}$ atau dalam $\mathrm{mmol}_{2}$ per kilogram.

Penentuan bilangan peroksida ini biasanya menggunakan titrasi iodometri dengan cara sbb :

1. Ditimbang \pm 5 gram sampel minyak ke dalam Erlenmeyer $250 \mathrm{ml}$

2. Ditambahkan dengan $30 \mathrm{ml}$ larutan asam asetat : chloroform (3:2) kemudian dikocok

3. Ditambahkan $0,5 \mathrm{ml}$ larutan $\mathrm{KI}$ jenuh kemudian dikocok

4. Didiamkan 1 menit dalam keadaan Erlenmeyer tertutup sambil sesekali digoyang setelah itu ditambahkan $30 \mathrm{ml}$ aquadest.

5. Campuran dititrasi dengan $0,01 \quad \mathrm{~N} \quad \mathrm{Na}_{2} \mathrm{~S}_{2} \mathrm{O}_{3}$ sampai warna kuning sampai hilang

6. Kemudian ditambahkan 0,5 ml larutan kanji 1\% setelah itu dititrasi kembali sampai warna biru hilang.

Perhitungan :

Bilangan Peroksida (PV)

=VTioxNTiox1000

Berat Sampel (gram)

\section{Analisa Bilangan Warna (} Absorbansi ).

warna ini $\begin{gathered}\text { Analisa kepekatan } \\ \text { menggunakan alat }\end{gathered}$ Spektrofotometr UV-Vis. Metode ini menentukan warna dengan membandingkan besarnya absorbansi yang didapat pada sampel, memakin besar absorbansinya maka menunjukkan warna minyak semakin keruh, artinya semakin jelek kualitasnya

Cara pengoperasian Spektrofotometer UV-Vis adalah dengan cara sebagai berikut :

1. Dinyalakan spektrofotometer dan tunggu sampai 20-30 menit agar pembacaan absorbansi bisa stabil.

2. Tempatkan larutan pembanding misalnya blangko dalam sel 
pertama sedangkan larutan yang dianalisis pada sel kedua.

3. Kemudian pilih foto sel yang cocok, agar panjang gelombang yang diperlukan dapat terliputi.

4. Letakkan sampel yang telah dimasukkan kedalam kuvet pada sample compartment.

5. Kita siap untuk menggunakan sistem.

6. Lampu hijau akan berkedip, hal ini bahwa menunjukkan pengukuran sedang berlangsung.

7. Jika spektrofotometer berhenti, hal ini menunjukkan bahwa pengukuran telah selesai.

8. Data absorbansi dan spektrum akan terbaca di komputer, yang berbentuk grafik hubungan antara panjang gelombang dengan absorbansi.

\section{Diagram Alir}

1. Diagram Alir Proses Penghilangan Bumbu (Despicing)

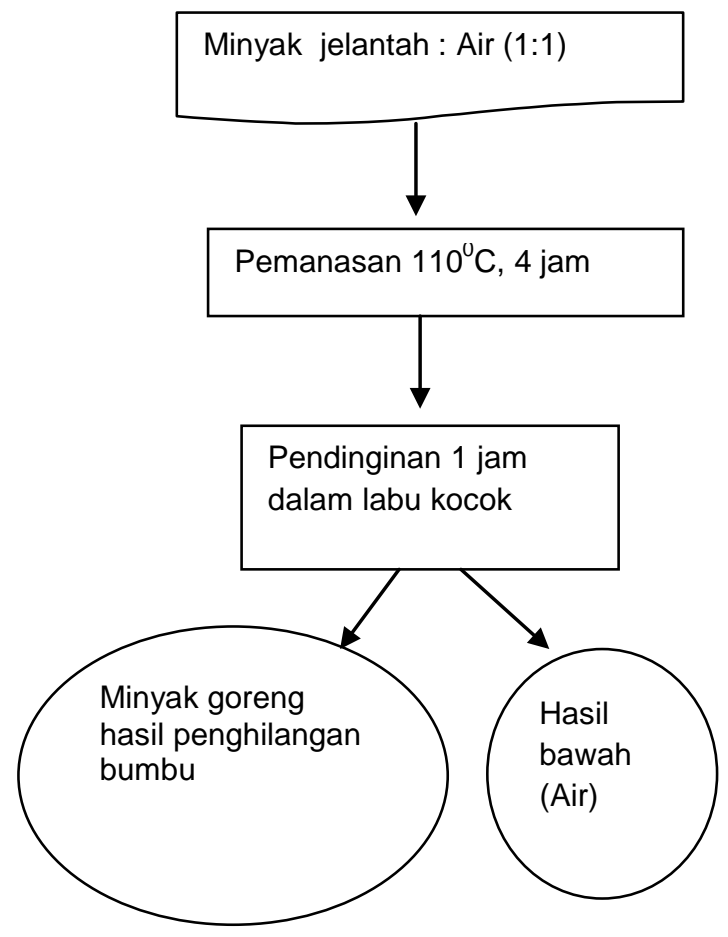

Gambar 1. Diagram Alir Proses Penghilangan Bumbu (Despicing)
2. Diagram Alir Proses Netralisasi

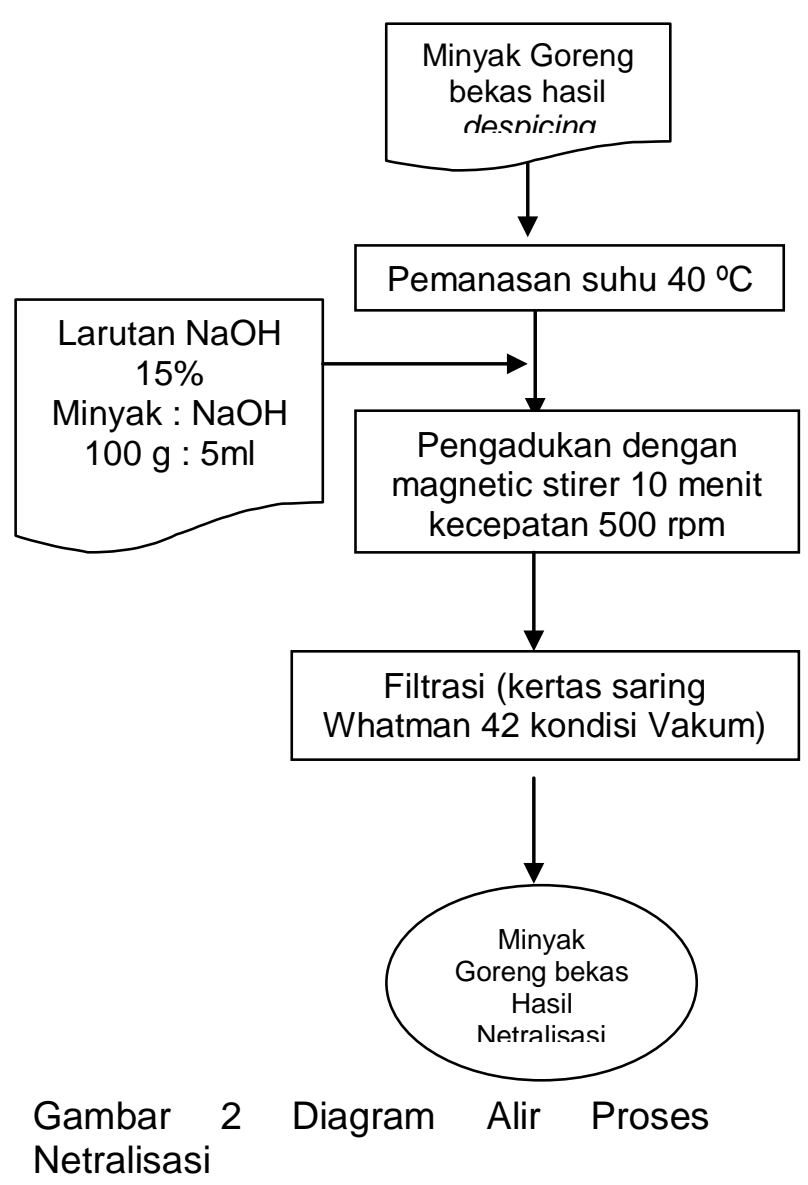

HASIL DAN PEMBAHASAN

Hasil Penelitian

1. Kadar Asam Lemak Bebas (Free Fatty Acid Value/FFA)

Dari penelitian yang telah dilakukan dalam meningkatkan kualitas minyak goreng bekas dengan penambahan buah mengkudu dan variabel temperatur dihasilkan asam lemak bebas sebagai berikut :

Tabel 1. Bilangan Asam dan Kadar Asam Lemak Bebas

\begin{tabular}{lll}
\hline $\begin{array}{l}\text { Variabel } \\
\text { Temperatur } \\
(\mathrm{oC})\end{array}$ & $\begin{array}{l}\text { Bilangan } \\
\text { Asam } \\
\text { (mgrek/mg) }\end{array}$ & $\begin{array}{l}\text { Kadar } \\
\text { Asam } \\
\text { Lemak } \\
\text { Bebas } \\
(\%)\end{array}$ \\
\hline 50 & 0.6633 & 0.4245 \\
\hline 60 & 0.5558 & 0.3557 \\
\hline 70 & 0.3293 & 0.2108 \\
\hline 80 & 0.3865 & 0.2474 \\
\hline 90 & 0.4677 & 0.2993 \\
\hline
\end{tabular}




\section{Bilangan Peroksida (Peroxide Value/PV)}

Dari penelitian yang telah dilakukan dalam meningkatkan kualitas minyak goreng bekas dengan penambahan buah mengkudu dan variabel temperatur dihasilkan Bilangan Peroksida (PV) sebagai berikut :

Tabel 2 Angka Bilangan Peroksida

\begin{tabular}{ll}
\hline $\begin{array}{l}\text { Temperatur } \\
(\mathbf{o C})\end{array}$ & $\begin{array}{l}\text { Bilangan } \\
(\mathbf{P V}) \\
(\mathbf{m e q} / \mathbf{k g})\end{array}$ \\
\hline 50 & 5.1101 \\
\hline 60 & 3.8643 \\
\hline 70 & 1.6500 \\
\hline 80 & 2.7155 \\
\hline 90 & 3.4603 \\
\hline
\end{tabular}

\section{Pembahasan}

Penelitian ini dilakukan untuk meningkatkan kualitas minyak goreng bekas dengan metode adsorpsi dan mempelajari pengaruh temperatur pada proses pemurnian terhadap kualitas minyak goreng bekas, sehingga dapat diketahui kondisi temperatur yang terbaik untuk memperbaiki kualitas minyak goreng bekas tersebut. Adsorben yang digunakan dalam penelitian ini adalah buah mengkudu. Mutu minyak pangan ditentukan oleh beberapa faktor antara lain warna, bilangan peroksida dan kadar asam lemak bebas (Ketaren, 1986). Oleh karena itu analisa yang dilakukan adalah analisa bilangan asam, kadar asam lemak bebas, bilangan peroksida dan Bilangan warna.

Penelitian ini meliputi Proses Penghilangan Bumbu (Despicing), Netralisasi, Pemucatan (Bleaching).

1. Pengaruh Temperatur pada Kadar Asam Lemak Bebas

Asam lemak bebas merupakan dasar untuk mengetahui umur minyak, kemurnian minyak, dan tingkat hidrolisa. Asam lemak bebas dengan kadar lebih dari 0,2 \% dari berat minyak mengakibatkan flavor yang tidak disukai, dapat mengakibatkan turunnya mutu dan nilai gizi bahan pangan tersebut, dan meracuni tubuh.
Bilangan asam yang besar menunjukkan asam lemak bebas yang besar, berasal dari hidrolisis minyak ataupun karena pengolahan yang kurang baik. Makin tinggi bilangan asam makin rendah kualitas suatu minyak.

Dari data pada tabel 1 , besarnya bilangan asam dan kadar asam lemak bebas yang diperoleh dari hasil adsorbsi minyak jelantah dengan buah mengkudu sebagai adsorben, dapat dilihat pada Gambar 1 dan Gambar 2 :

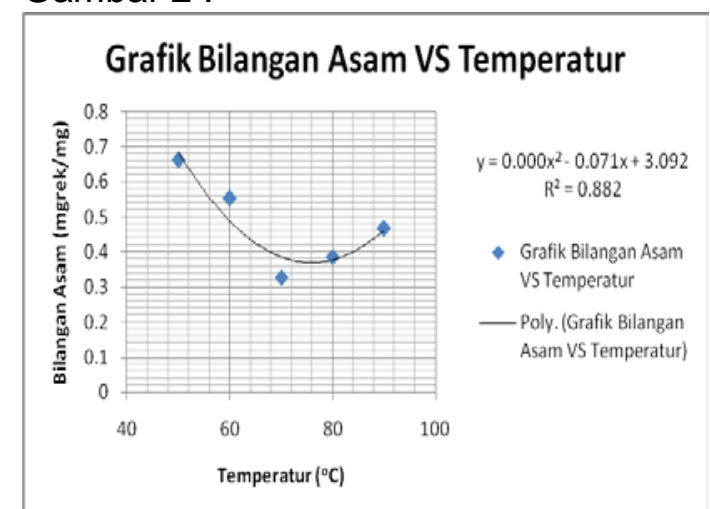

Gambar 1. Pengaruh Temperatur terhadap Bilangan Asam Minyak Jelantah hasil adsorbsi

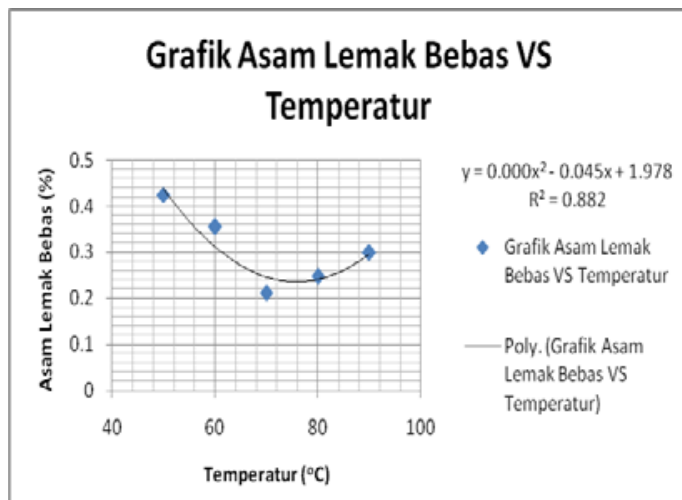

Gambar 2. Pengaruh Temperatur terhadap Kadar asam lemak bebas Minyak Jelantah hasil adsorbsi

Dari Gambar 1 dan 2 di atas dapat dilihat minyak goreng bekas yang belum diproses untuk dimurnikan memiliki kadar asam lemak bebas sebesar $1.2765 \%$. Sedangkan minyak goreng bekas yang telah dimurnikan kadar asam lemak bebasnya menurun pada kisaran angka 0.4245-0.2108 \%.

Pada temperatur $50^{\circ} \mathrm{C}$ dalam proses bleaching minyak goreng bekas 
yang teradsorbsi masih sedikit sehingga \% FFA-nya yaitu $0.4245 \%$, tetapi dengan adanya kenaikan temperatur $10^{\circ} \mathrm{C}$ menjadi $60^{\circ} \mathrm{C}$ kadar FFA-nya semakin turun yaitu $0.3557 \%$ sampai mencapai temperatur $700 \mathrm{C}$ dengan \% FFAnya yaitu $0,2108 \%$. Sedangkan pada temperatur $80^{\circ} \mathrm{C} \%$ FFA nya yang didapat mengalami kenaikan dibandingkan temperatur $70^{\circ} \mathrm{C}$ yaitu $0,2474 \%$ dan pada temperatur $90^{\circ} \mathrm{C}$ semakin tinggi \% FFA nya yaitu $0,2993 \%$. Dan apabila temperatur terus dinaikkan maka adsorpsi pada minyak kurang efektif karena akan mengalami degradasi termal pada suhu tinggi dan zat adsorben yang dipakai mengalami kerusakan.

Nilai efisiensi dari proses dapat dilihat dari tabel 3 Dengan nilai kadar asam lemak bebas awal (sebelum adsorbsi) $=1.2765 \%$.

Tabel 3 Kadar Asam Lemak Bebas terhadap Effisiensi

Dari tabel 3 dapat dilihat bahwa asam sitrat pada metode pemurnian ini mampu menetralkan beberapa asam lemak bebas pada minyak goreng bekas hingga 66.75 - $83.49 \%$. Pada peneitian ini didapatkan temperatur optimum adsorbsi pada penambahan buah mengkudu adalah $70^{\circ} \mathrm{C}$ dengan kadar asam lemak bebas $0.2108 \%$ minyak.

\section{Pengaruh Temperatur pada Bilangan Peroksida}

Reaksi oksidasi pada minyak mulamula akan membentuk peroksida dan hidroperoksida, yang selanjutnya akan terkonversi menjadi aldehida, keton dan asam-asam lemak bebas. Randicity (ketengikan) terbentuk oleh adanya aldehida, bukan terbentuk oleh adanya peroksida. Jadi kenaikan angka peroksida (PV) hanya indikator dan peringatan bahwa minyak sebentar lagi akan berbau tengik.

Reaksi pembentukan peroksida pada minyak diakibatkan oleh reaksi oksidasi oleh oksigen dengan sejumlah asam lemak tidak jenuh, dan reaksi ini dipercepat dengan pemanasan.

Analisis angka peroksida minyak goreng bekas, dan hasil reprocessing dilakukan dengan metode iodometri, dengan cara sejumlah minyak dilarutkan dalam campuran asetat : kloroform yang mengandung $\mathrm{KI}$, maka akan terjadi pelepasan iodin (12)

Dari tabel 2 Angka bilangan peroksida yang diserap oleh buah mengkudu sebagai adsorben, dapat dilihat pada grafik seperti dibawah ini :

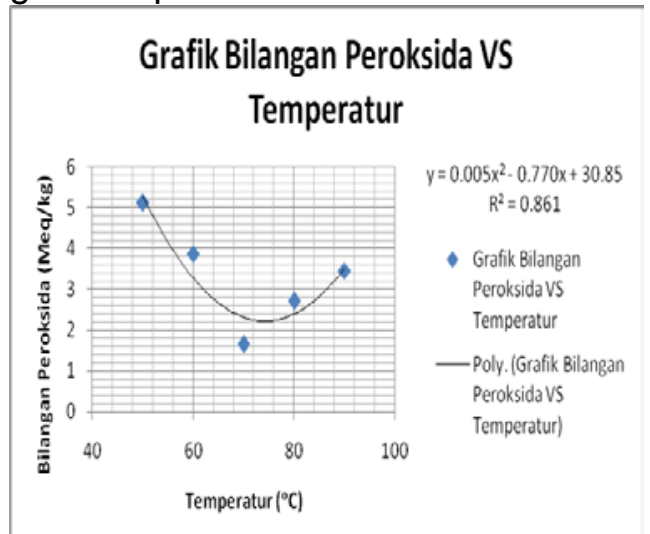

Gambar 3. Pengaruh Temperatur

\begin{tabular}{l|l|l}
\hline $\begin{array}{l}\text { Temperatu } \\
r(\mathrm{oC})\end{array}$ & $\begin{array}{l}\text { KadarAsa } \\
\text { m Lemak } \\
\text { Bebas (\%) }\end{array}$ & $\begin{array}{l}\text { Effisiensi } \\
(\%)\end{array}$ \\
\hline 50 & 0.4245 & 66.75 \\
\hline 60 & 0.3557 & 72.13 \\
\hline 70 & 0.2108 & 83.49 \\
\hline 80 & 0.2474 & 80.62 \\
\hline 90 & 0.2993 & 76.55 \\
\hline
\end{tabular}

terhadap Bilangan Peroksida

Dari gambar 3 dapat dilihat hasil analisa angka peroksida dari minyak goreng bekas (minyak jelantah) sebelum dimurnikan dan minyak goreng yang telah dimurnikan.

Nilai efisiensi dari proses dapat dilihat dari tabel.5 Dengan nilai kadar angka peroksida awal (sebelum adsorbsi) $=9.9496$.

Tabel.4 Angka Peroksida terhadap Effisiensi 


\begin{tabular}{l|l|l}
\hline $\begin{array}{l}\text { Temperatur } \\
(\mathbf{o C})\end{array}$ & $\begin{array}{l}\text { Angka } \\
\text { Peroksida } \\
\text { (meq/kg) }\end{array}$ & $\begin{array}{l}\text { Effisiensi } \\
(\%)\end{array}$ \\
\hline 50 & 5.1101 & 48.64 \\
\hline 60 & 3.8643 & 61.16 \\
\hline 70 & 1.6500 & 83.42 \\
\hline 80 & 2.7155 & 72.71 \\
\hline 90 & 3.4603 & 65.22 \\
\hline
\end{tabular}

Dari tabel 4. menunjukkan bahwa penambahan buah mengkudu pada metode ini mampu menurunkan beberapa senyawa-senyawa peroksida yang menyebabkan kerusakan pada minyak goreng bekas hingga 48.64$83.42 \%$.

Pada penelitian ini hasil analisa bilangan peroksida terjadi fluktuatif disebabkan kemampuan dari buah mengkudu sendiri pada temperatur rendah buah mengkudu belum mampu menurunkan senyawa peroksida secara optimal, tetapi pada temperatur $70^{\circ} \mathrm{C}$ buah mengkudu secara optimal dan signifikan menurunkan senyawa. Sedangkan pada temperatur kenaikan $10^{\circ} \mathrm{C}$ yaitu $80-90^{\circ} \mathrm{C}$ hasil analisanya sedikit naik.

\section{Pengaruh Temperatur pada Kepekatan Warna ( Absorbansi )}

Absorbsi cahaya UV-Vis mengakibatkan transisi elektronik, yaitu promosi elektron-elektron dari orbital keadaan dasar yang berenergi rendah ke orbital keadaan tereksitasi berenergi lebih tinggi. Semakin besar absorbansi dari suatu larutan maka larutan tersebut semakin keruh, dan semakin buruk pula kualitas larutan tersebut.

Tabel 5 menunjukkan pengaruh temperatur terhadap Absorbansi pada minyak dan dapat pula dilihat pada gambar 4.

Tabel 5 Absorbansi pada panjang gelombang $450 \mathrm{~nm}$ terhadap Effisiensi

\begin{tabular}{lll}
\hline \multicolumn{3}{c}{ Abs pada } \\
Temperatur & panjang & Effsiensi \\
\hline \multirow{3}{*}{ gelombang } \\
\end{tabular}

\begin{tabular}{lll}
\hline 50 & 4.690 & 53.10 \\
\hline 60 & 3.981 & 60.19 \\
\hline 70 & 0.820 & 91.80 \\
\hline 80 & 2.134 & 78.66 \\
\hline 90 & 3.546 & 64.54 \\
\hline
\end{tabular}

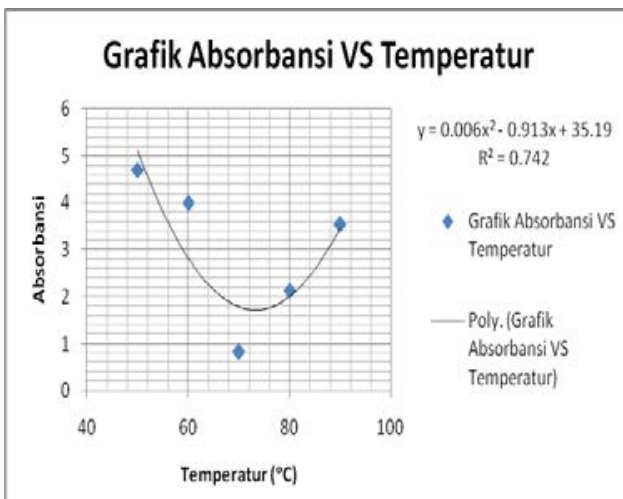

Gambar 4. Pengaruh temperatur terhadap absorbansi minyak

Dari gambar 4 dapat dilihat hasil nilai absorbansi yang didapatkan dengan pembacaan dengan menggunakan instrumen Spektrofotometri adalah minyak yang telah dimurnikan dengan temperatur $70^{\circ} \mathrm{C}$ memiliki nilai absorbansi yang paling kecil dibandingkan waktu pemurnian yang lainnya.

\section{KESIMPULAN}

Dari data hasil penelitian laboratorium dapat diambil kesimpulan sebagai berikut :

1. Buah mengkudu dapat dijadikan adsorben pada pemurnian minyak goreng bekas.

2. Temperatur pada proses penambahan buah mengkudu mempengaruhi titik optimum hasil adsorbsi minyak goreng bekas.

3. Buah mengkudu bisa digunakan baik dalam menetralkan senyawa-senyawa peroksida penyebab kerusakan kerusakan minyak dan menetralkan asamasam lemak bebas dibandingkan penurunan bilangan warna. 


\section{DAFTAR PUSTAKA}

AOCS. 1997. Official Methods and Recomenden Practices of The AOCS. Fifth Edition. Champaign. Illinois.

Bernasconi, G, Gerster, H, dan Hauser H. 1995. Teknologi Kimia Bagian 2.

Edisi pertama Terjemahan Lienda Handojo Pradnya Paramita. Jakarta

Handayani, M dan Sulistiyono, E. 2009. UJI PERSAMAAN LANGMUIR DAN FREUNDLICH PADA PENYERAPAN LIMBAH CHROM (VI) OLEH ZEOLIT. Prosiding Seminar Nasional Sains dan Teknologi Nuklir PTNBR BATAN Bandung.
Ketaren, S. 1986. Pengantar Teknologi Minyak dan Lemak Pangan. UIPress. Jakarta.

Oscik, J. 1991. Adsorption, Edition Cooper I.L. John Wiley and Sons. New York.

Winarno, F. G. 1997. Kimia Pangan dan Gizi. Gramedia Pustaka Utama. Jakarta. 